\title{
Land use influence on eutrophication-related water variables: case study of tropical rivers with different degrees of anthropogenic interference
}

\author{
Influência do uso e ocupação do solo sobre as variáveis da água relacionadas \\ à eutrofização: estudo de caso de rios tropicais com diferentes níveis de \\ interferência antrópica
}

Davi Gasparini Fernandes Cunha, Flávia Bottino and Maria do Carmo Calijuri

Departamento de Hidráulica e Saneamento - SHS, Escola de Engenharia de São Carlos - EESC, Universidade de São Paulo - USP, Av. Trabalhador São-Carlense, 400, CEP 13566-590, São Carlos, SP, Brazil e-mail: davig@sc.usp.br, flaviabottino@yahoo.com.br, calijuri@sc.usp.br

\begin{abstract}
Aim: The importance of land use patterns on the occurrence and magnitude of eutrophication-related variables (total phosphorus, total nitrogen, chlorophyll-a and total suspended solids) was assessed for three tropical rivers located in the same watershed (Ribeira do Iguape watershed, São Paulo State, Brazil); Methods: To obtain the percentages of land use by sub-basin, thematic maps were carefully analyzed and a Planimeter was used. Land use patterns were classified as: forest, agriculture, pasture, water, urban area, grassland and others (e.g. clouds and shadows). Samples for determination of Total Phosphorus (TP), Total Nitrogen (TN), Chlorophyll- $a$ (Chl-a) and Total Suspended Solids (TSS) were collected from the three Brazilian rivers; Results: Canha River, more preserved (about $70 \%$ of its catchment area is covered by forests), presented some sites characterized as oligotrophic and others as mesotrophic. Pariquera-Açu River in turn showed great oscillation in TSI (Trophic State Index) and Jacupiranguinha River was the most influenced by the eutrophication (TSI results were characteristic of hypereutrophic systems). In this river, the concentrations of total phosphorus reached $124 \mathrm{mg} . \mathrm{L}^{-1}$ in the sample site that reflects the impacts suffered by the aquatic environment due to the discharge of an industrial effluent; Conclusions: The results suggested that the trophic level of the rivers was associated with land use found in their drainage areas and with the specific characteristics of each lotic system, such as presence or absence of riparian vegetation, for instance. It is expected that these results contribute to the advancement of Limnology and serve as stimulus and basis for the beginning of plans and programs to revitalize the studied aquatic ecosystems of Baixo Ribeira do Iguape watershed (SP, Brazil).
\end{abstract}

Keywords: Brazilian rivers, land use; nutrients, Ribeira do Iguape watershed, water quality, water resources management.

Resumo: Objetivo: A importância dos padrōes de uso e ocupação do solo na ocorrência e magnitude das variáveis da água relacionadas à eutrofização foi avaliada para três rios tropicais localizados na mesma bacia hidrográfica (Bacia do Rio Ribeira de Iguape, Estado de Sáo Paulo, Brasil); Métodos: Para obter as porcentagens de uso e ocupação do solo de cada subbacia, mapas temáticos foram cuidadosamente analisados e um planímetro foi empregado. Os padrōes de uso do solo foram tipificados de acordo com a seguinte classificação: floresta, área agrícola, pasto, água, área urbana, campos e outros (e.g. nuvens e sombras). Amostras para quantificação de fósforo total, nitrogênio total, clorofila- $a$ e sólidos suspensos totais foram coletadas nos três rios estudados; Resultados: O Rio Canha, mais preservado (cerca de $70 \%$ da sua área de influência ocupada por florestas), apresentou-se em alguns pontos como oligotrófico e em outros, como mesótrofico, Já o Rio Pariquera Açu sofreu grande variação do IET (Índice de Estado Trófico) e o Rio Jacupiranguinha foi o sistema mais impactado pelo processo de eutrofização (IET característico de sistemas hipereutróficos). Nesse rio, as concentraçôes de fósforo total atingiram $124 \mathrm{mg} . \mathrm{L}^{-1} \mathrm{em}$ uma estação amostral que reflete os impactos sofridos pelo ambiente aquático em decorrência do lançamento de um efluente industrial; Conclusóes: Os resultados sugeriram que o grau de trofia dos rios variou com o tipo de uso e ocupação do solo verificado nas respectivas áreas de drenagem e com as características intrínsecas de cada sistema aquático, como presença ou ausência de mata ciliar, por exemplo. Espera-se que os resultados apresentados contribuam para o avanço da Limnologia e sirvam como base e estímulo para o início de programas de revitalização dos ecossistemas aquáticos do Baixo Ribeira de Iguape (SP).

Palavras-chave: bacia hidrográfica do Rio Ribeira de Iguape, gerenciamento dos recursos hídricos, nutrientes, qualidade da água, rios brasileiros, uso e ocupação do solo. 


\section{Introduction}

The environment embraces temporal and nonlinear phenomena with multiple phases, various properties and, therefore, it is characterized as a complex system (Odum, 1971). Equally intricate is the human environment, that originated from anthropogenic activities, whose impacts play an important role on natural environment modification. The consequences of these impacts are more or less absorbed by the Earth, according to the internal autoregulation ability of the ecosystems. When it comes to the water resources, intense human interference around the world, through point and diffuse pollution sources and other impacts (e.g. dam construction, mining), might cause irreversible damage to the watercourses, inhibiting the running of the auto depuration process in the affected environment and imposing restrictions on water availability in qualitative and quantitative terms.

Changes in the water quality may be coupled with watershed health and sanitary conditions, physical and chemical soil specific characteristics and land slope. The basic principle for controlling adverse and undesirable effects to the water is managing the drainage basin land use, taking into account the peculiarities of the region. These factors are responsible for regulating the load of nutrients, for example, to be carried to the water bodies (Basnyat et al., 2000; Wood et al., 2005). In this regard, eutrophication is one of the environmental problems of greatest concern due to its negative influence on multiple uses of water and to its social, economical and environmental implications (Dodds et al., 1998; Smith et al., 1999; Dodds et al., 2002; Smith, 2003; Khan and Ansari, 2005; Ribeiro et al., 2005; Calijuri et al., 2006; Dodds, 2006).

On one hand, point sources of water pollution may be related either to domestic or to industrial effluents. Domestic effluents are able to increase the oxygen demand in the water streams (through the input of organic matter) and to threaten the aquatic biota. Critical fate is that stabilization ponds, a widespread alternative for wastewater treatment in Brazil, may present poor efficiency on BOD (Biochemical Oxygen Demand) reduction if inadequately operated and irrelevant percentages of nutrients removal, like phosphorus and nitrogen (Naval and Santos, 2000; Oliveira et al., 2001). Untreated industrial effluents in turn may contribute to the raise of heavy metals, inorganic and organic compounds concentrations in the water and to also the damage of biological communities (e.g.
Nedeau et al., 2003; Nyamangara et al., 2008; Arimoro, 2009).

Differently, diffuse pollution sources depend on land use in the watershed. Many researches have studied the influence of land use on streamwater nutrients, mainly processed by the runoff effect, and their ecology implication, emphasizing the role of rural areas (e.g. Buck et al., 2004; SalviaCastellví et al., 2005; Morgan et al., 2006; Jarvie et al., 2008; Piscart et al., 2009) and urban ones (e.g. Taylor et al., 2005; Kim et al., 2007).

Most of the articles previously mentioned were developed in temperate regions, what makes evident the lack of studies in tropical systems (Calijuri et al., 2008). In this regard and aiming to fill this gap, the goal of this study was to analyze the influence of land use on eutrophication-related water variables in three tropical rivers with different levels of anthropogenic interference, but located in the same watershed. These human impacts included discharges of domestic and industrial effluents, besides rural and urban runoff. Therefore, this research focused on assessing the key factors that control and exert influence on biomass growth in response to nutrients enrichment in tropical aquatic systems from a Brazilian watershed, mainly those related to the peculiarities of land use.

\section{Study Area}

The sampled Brazilian rivers are all located in Ribeira do Iguape watershed (geographic coordinates limits: $23^{\circ} 30^{\prime} ; 25^{\circ} 30^{\prime} \mathrm{S}$ and $46^{\circ} 50^{\prime}$; $\left.50^{\circ} 00^{\prime} \mathrm{W}\right)$, in the most Southern part of São Paulo State, Brazil (Figure 1), constituting the Water Resources Management Unit 11, UGRHI 11 (CETESB, 2005). This watershed presents $16,607 \mathrm{~km}^{2}$ of drainage area and encloses 23 cities with 358,565 inhabitants $(234,124$ live in the rural area). The main economic activities in the region are based on agriculture, fishing, food industry and calcium phosphate mining (the most harmful to the environment). Also, Ribeira do Iguape River Basin is a strategic region in ecological terms, since it shelters remaining fragments of Mata Atlântica Tropical Forest, although there is a continuous process of degradation due to accelerated urban growth, deforestation for agriculture and establishment of industrial activity. This region faces barriers to its social development, with high rates of infant mortality and analphabetism, lack of medical and health care and sanitation structures, resulting in low life quality for the local citizens (SEADE, 2000, 2003, 2006). 


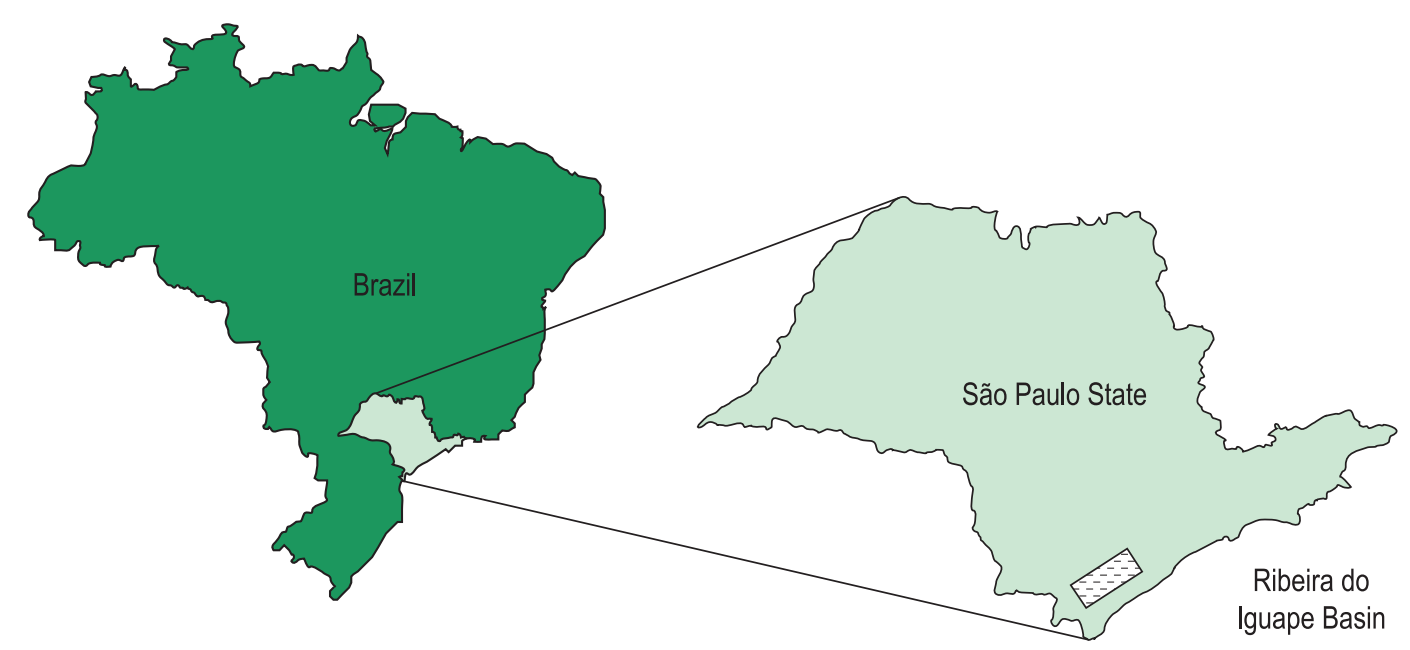

Figure 1. Schematic map showing Ribeira do Iguape Basin, São Paulo State, Brazil, where the three sampled Brazilian rivers are located.

Canha River influence area $\left(125 \mathrm{~km}^{2}\right)$ is characterized by the presence of riparian vegetation and by some rural properties with banana cultivation. Moreover, it is important to stress that its water is used for human supplying by Jacupiranga city (SP). Canha River is submitted neither to domestic nor to industrial effluents; it is minimally affected by urban runoff and significantly influenced by rural runoff. For this reason, this river was considered as low affected by anthropogenic impacts. On the other hand, Pariquera-Açu River receives the effluent of a stabilization pond that treats the domestic wastewater of Pariquera-Açu city, approximately

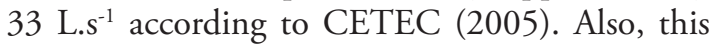
river is subjected to both urban and rural runoff and some areas present exposed soil. Nevertheless, Pariquera-Açu River is not affected by industrial effluents. These factors justified the assuming that this aquatic system presents a moderate level of anthropogenic interference. At last, Jacupiranguinha River is severely affected by industrial effluent (from fertilizers manufacturing), treated wastewater effluents from stabilization pond $\left(38 \mathrm{~L} . \mathrm{s}^{-1}\right)$ and both urban and rural runoff.

\section{Methods}

To obtain the percentages of land use by subbasin, thematic maps were carefully analyzed and a Planimeter, which is an equipment employed to obtain areas of flat surfaces, was used. Land use patterns were classified as: forest, agriculture, pasture, water, urban area, grassland and others (e.g. clouds and shadows). The cartographic base (spatial scale: $1: 50,000)$ was obtained in IBGE (2003) and converted into land use maps by Loures (2008), using a spatial scale of 1:100,000.
Although samplings were conducted in different periods for the rivers and this certainly impose the need of prudence when analyzing results, the conclusions of this research are valid and might contribute for the watershed management. For Canha River, the samplings were conducted in a single day in September/06, January, April and July/07. For Pariquera-Açu River, the three-day campaigns took place on January, April, July and October/07. Finally, sampling periods in Jacupiranguinha River, also during three consecutive days, embraced the following months: January, April, July and October/05.

Samples for determination of Total Phosphorus (TP), Total Nitrogen (TN), Chlorophyll- $a(\mathrm{Chl}-a)$ and Total Suspended Solids (TSS) were collected from the three Brazilian Rivers. For all these rivers, the selection of the sampling stations (Table 1) considered the presence of strategic elements, like rural properties, urban areas and Wastewater Treatment Plants and industrial effluents (downstream them).

Eutrophication-related nutrients and TSS were determined in subsurface samples (about $10 \mathrm{~cm}$ below the water surface) following APHA (1999) methods and Chl- $a$ concentrations were determined by ethanol extraction (Nush, 1980 modified by NEN, 1981). Complementary data about land use of the study area as well as some information concerning the water quality were obtained from other researches (e.g. Moccellin et al., 2009; Calijuri et al., 2008; Cunha et al., 2008; Bottino and Mendiondo, 2009; Loures et al., 2009; Lugão et al., 2009). 
Table 1. Geographic coordinates (latitude and longitude) of each sampling station in Canha, Pariquera-Açu and Jacupiranguinha Rivers.

\begin{tabular}{lcccccc}
\hline & Spring & Rural area & Urban area & WTP effluent & Industrial effluent & Mouth \\
\hline Canha River & $24^{\circ} 52^{\prime} 08^{\prime \prime} \mathrm{S}$ and & $24^{\circ} 47^{\prime} 09^{\prime \prime} \mathrm{S}$ and & $24^{\circ} 41^{\prime} 19^{\prime \prime} \mathrm{S}$ and & Absent & Absent & $24^{\circ} 41^{\prime} 19^{\prime \prime} \mathrm{S}$ and \\
& $47^{\circ} 57^{\prime} 55.3^{\prime \prime} \mathrm{W}$ & $47^{\circ} 58^{\prime} 20.2^{\prime \prime} \mathrm{W}$ & $47^{\circ} 59^{\prime} 44^{\prime \prime} \mathrm{W}$ & & & $47^{\circ} 59^{\prime} 54^{\prime \prime} \mathrm{W}$ \\
Pariquera-Açu & $24^{\circ} 44^{\prime} 54^{\prime \prime} \mathrm{S}$ and & $24^{\circ} 43^{\prime} 46^{\prime \prime} \mathrm{S}$ and & $24^{\circ} 37^{\prime} 57^{\prime} \mathrm{S}$ and & $24^{\circ} 42^{\prime} 03^{\prime \prime} \mathrm{S}$ and & Absent & $24^{\circ} 37^{\prime} 56^{\prime \prime} \mathrm{S}$ and \\
River & $47^{\circ} 56^{\prime} 58^{\prime \prime} \mathrm{W}$ & $47^{\circ} 56^{\prime} 28^{\prime \prime} \mathrm{W}$ & $47^{\circ} 50^{\prime} 59^{\prime \prime} \mathrm{W}$ & $47^{\circ} 52^{\prime} 55^{\prime \prime} \mathrm{W}$ & & $47^{\circ} 44^{\prime} 12^{\prime \prime} \mathrm{W}$ \\
Jacupiranguinha & $24^{\circ} 43^{\prime} 11^{\prime \prime} \mathrm{S}$ and & $24^{\circ} 43^{\prime} 38^{\prime \prime} \mathrm{S}$ and & $24^{\circ} 43^{\prime} 02^{\prime \prime} \mathrm{S}$ and & $24^{\circ} 43^{\prime} 22^{\prime \prime} \mathrm{S}$ and & $24^{\circ} 43^{\prime} 05^{\prime \prime} \mathrm{S}$ and & $24^{\circ} 43^{\prime} 02^{\prime \prime} \mathrm{S}$ and \\
River & $48^{\circ} 10^{\prime} 26^{\prime \prime} \mathrm{W}$ & $48^{\circ} 05^{\prime} 55^{\prime \prime} \mathrm{W}$ & $48^{\circ} 03^{\prime} 00^{\prime \prime} \mathrm{W}$ & $48^{\circ} 05^{\prime} 37^{\prime \prime} \mathrm{W}$ & $48^{\circ} 05^{\prime} 10^{\prime \prime} \mathrm{W}$ & $48^{\circ} 03^{\prime} 00^{\prime \prime} \mathrm{W}$ \\
\hline
\end{tabular}

For all sampled stations, Trophic State Index (TSI) was calculated using mean, maximum and minimum concentrations of TP and Chl- $a$, through Equations 1, 2 and 3 (Lamparelli, 2004), especially designed for tropical lotic ecosystems.

$\mathrm{IET}=\frac{\mathrm{IET}(\mathrm{Chl}-\alpha)+\mathrm{IET}(\mathrm{TP})}{2}$

$\operatorname{IET}(\mathrm{Chl}-\alpha)=10\left[6\left(\frac{-0,7-0,6 \ln (\mathrm{Chl}-\alpha)}{\ln (2)}\right)\right]-20$

$\operatorname{IET}(\mathrm{PT})=10\left[6\left(\frac{0,42-0,36 \ln (\mathrm{PT})}{\ln (2)}\right)\right]-20$

The TSI is a useful tool for assessing the trophic state level of aquatic systems, mainly in the case of a comparative regional study (Marques et al., 2003; Garnier et al., 2005). The results for the three sampled rivers may offer subsides to environmental recovering plans for the respective sub-basins and also of the whole watershed in which these ecosystems are located.

The results of water quality are presented in their mean, minimum and maximum values for all the variables and also for the TSI values. The total number of analyzed samples for each river $(\mathrm{N})$ is also showed for each case.

\section{Results}

The land use percentages (Figures 2, 3 and 4), which were calculated for each sub-basin, revealed that Canha River drainage area is predominantly occupied by forest (about 70\%), followed by agricultural areas $(9 \%)$, characterizing a relatively well-preserved sub-basin. In this case, urban area represented only $1 \%$. Although reduced in percentage terms, forest is also preponderant in Pariquera-Açu sub-basin (30\%), followed by grassland (28\%) and agriculture (18\%). For Jacupiranguinha River, at last, agricultural activities and urban occupation are present in relative larger areas (27 and 3\% of the sub-basin total area, respectively) and the percentage of forest is approximately $57 \%$.

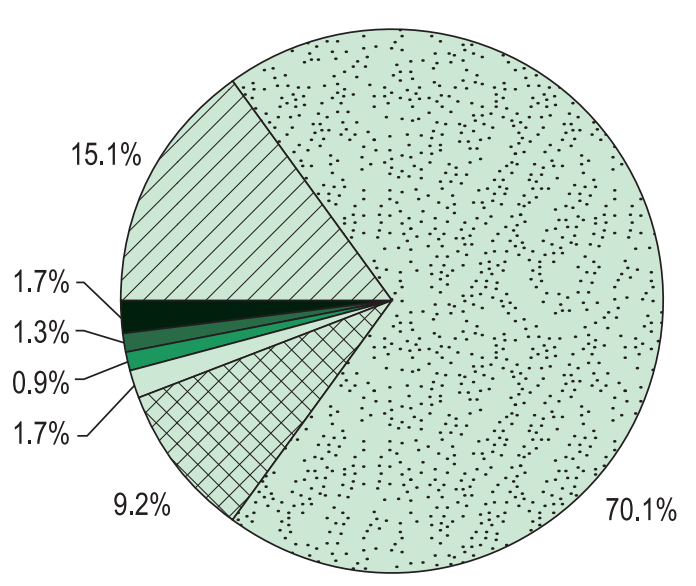

. Forest $邓$ Agriculture $\square$ Pasture $\square$ Water Urban area $\square$ Grassland $\square$ Others

Figure 2. Percentages of land use (\%) in Canha River influence area.

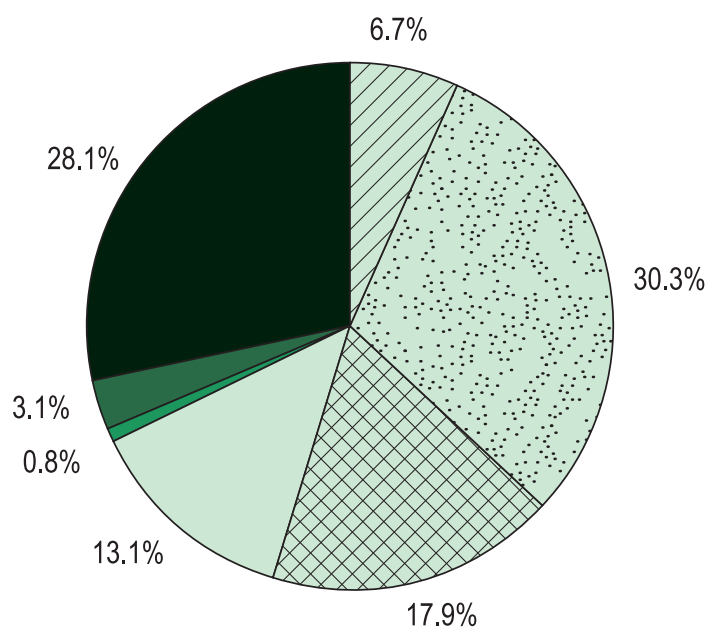

$\square$ Forest $\square$ Agriculture $\square$ Pasture $\square$ Water Urban area Grassland $\square$ Others

Figure 3. Percentages of land use (\%) in Pariquera-Açu River influence area.

For total phosphorus concentrations (Figure 5), there were clear gradients among the three rivers. Canha River presented the lowest concentrations and the smallest variations for all sampling 


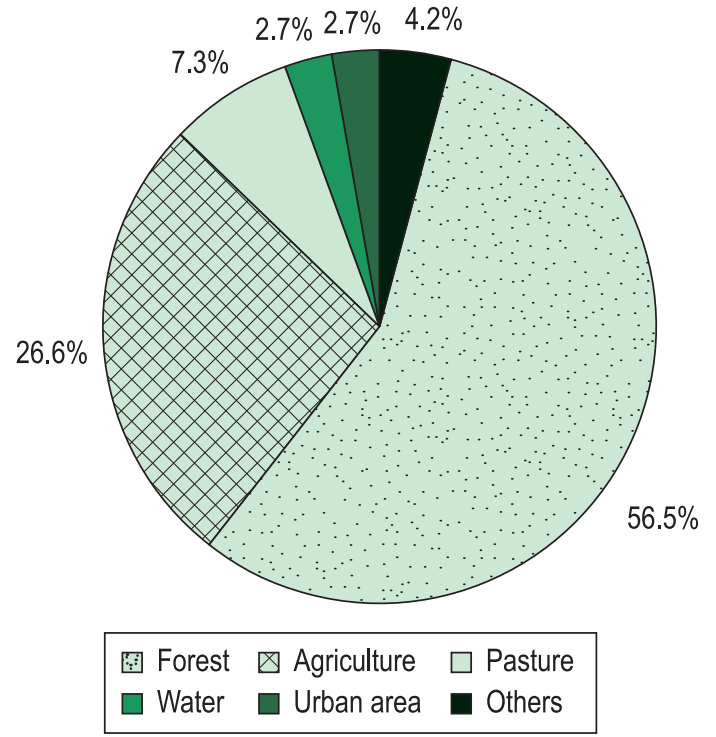

Figure 4. Percentages of land use (\%) in Jacupiranguinha River influence area.

stations. For Pariquera-Açu River, total phosphorus increment was observed in the stations that are submitted to the urban area influence and to the WTP effluent impact. Also for this river, the maximum TP concentration was $474.8 \mu \mathrm{g} . \mathrm{L}^{-1}$, found in the river mouth. At this site, the lentic behavior favored the growth of aquatic macrophytes. At last, Jacupiranguinha River presented the most critical situation (maximum TP concentration of $123,920.0 \mu \mathrm{g} . \mathrm{L}^{-1}$ in the station influenced by the industrial discharge).

Total nitrogen concentrations (Figure 6) presented an inverse behavior in comparison to phosphorus ones. Maximum values were obtained in Canha River, followed by Pariquera-Açu and Jacupiranguinha Rivers. In the urban area, for instance, Canha River presented $6.8 \mathrm{mg} . \mathrm{L}^{-1}$ as maximum concentration for TN. For all rivers, nitrogen concentrations showed an increase tendency from the respective springs to the urban area (for Canha River) and to the WTP effluent (for Pariquera-Açu and Jacupiranguinha River). Downstream these stations, in general, the concentrations decreased, reaching concentrations equal or lower than $3 \mathrm{mg} \cdot \mathrm{L}^{-1}$.

Chl-a concentrations (Figure 7) fluctuated between $<0.1 \mu \mathrm{g} . \mathrm{L}^{-1}$ (Canha River and Pariquera-Açu River - Springs; Jacupiranguinha River - Urban and Industrial areas) and $19.5 \mu \mathrm{g} . \mathrm{L}^{-1}$ (Jacupiranguinha River - Rural area). The stations located in the severely affected river, Jacupiranguinha River, presented higher oscillation of Chl- $a$ concentrations, which is characteristic of an eutrophic environment.

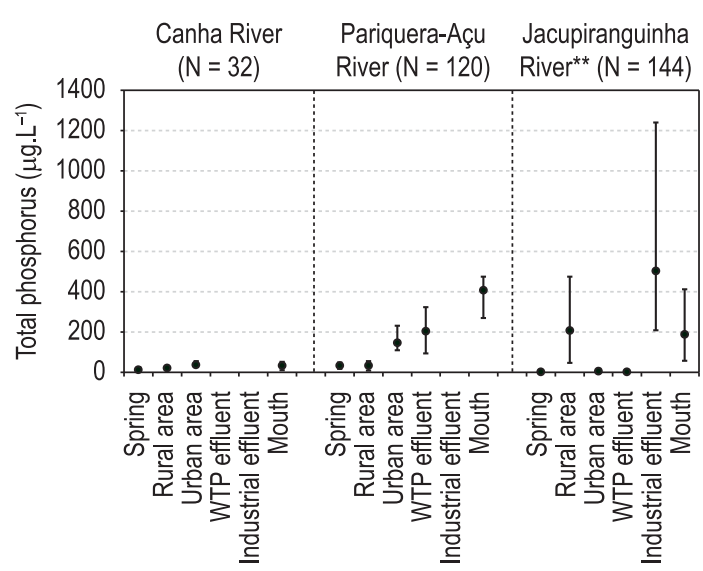

Figure 5. Mean $(\bullet)$, minimum $(\perp)$ and maximum $(T)$ Total Phosphorus concentrations ( $\mu$ g. $\left.L^{-1}\right)$ in Canha, Pariquera-Açu and Jacupiranguinha Rivers, besides the number of samples $(\mathrm{N})$ for each case. ${ }^{* *} \mathrm{TP}$ concentrations in Jacupiranguinha River were divided by 100 to facilitate the visualization.

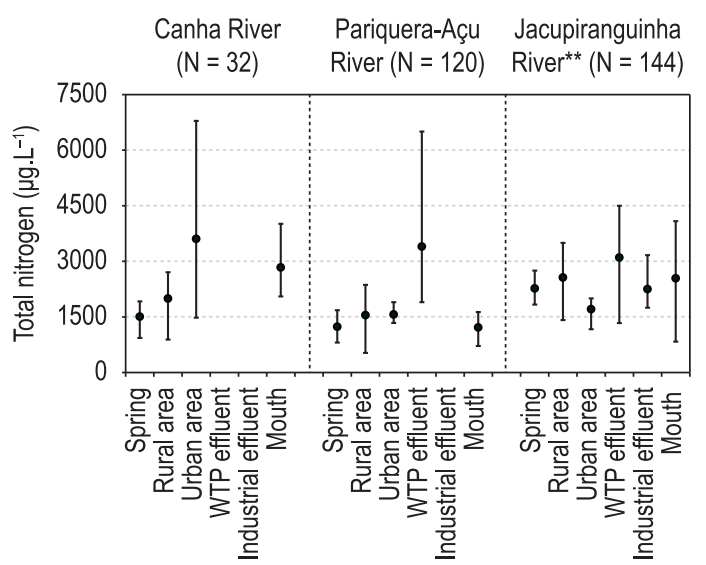

Figure 6. Mean $(\bullet)$, minimum $(\perp)$ and maximum $(T)$ Total Nitrogen concentrations ( $\mu$ g. $\left.\mathrm{L}^{-1}\right)$ in Canha, Pariquera-Açu and Jacupiranguinha Rivers, besides the number of samples $(\mathrm{N})$ for each case.

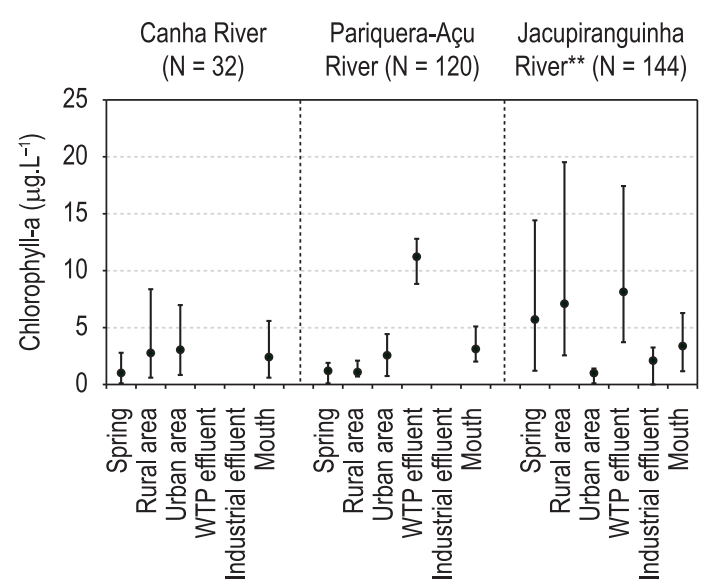

Figure 7. Mean $(\bullet)$, minimum $(\stackrel{\perp}{)}$ and maximum $(\mathrm{T})$ Chlorophyll-a concentrations ( $\left.\mu \mathrm{g} . \mathrm{L}^{-1}\right)$ in Canha, Pariquera-Açu and Jacupiranguinha Rivers, besides the number of samples $(\mathrm{N})$ for each case. 
In contrast, this variation was smaller in Canha and Pariquera-Açu Rivers. As a general pattern, Chl-a concentrations were higher in the sampling stations submitted to the impacts of rural areas and WTP effluents.

TSS concentrations (Figure 8) presented low, moderate and high oscillations in Canha, PariqueraAçu and Jacupiranguinha Rivers, respectively. In general, TSS concentrations in Canha and Pariquera-Açu Rivers were lower than 50 mg. $\mathrm{L}^{-1}$. Mean concentrations reached $15.4 \mathrm{mg} . \mathrm{L}^{-1}$ (Canha River - Mouth), 38.5 mg.L. $\mathrm{L}^{-1}$ (Pariquera-Açu River - Urban area) and 100.1 mg.L $\mathrm{L}^{-1}$ (Jacupiranguinha River - Rural area).

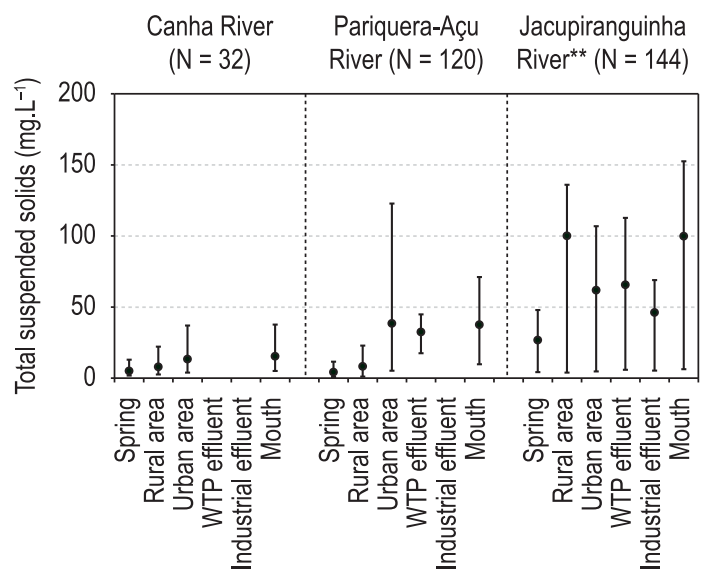

Figure 8. Mean $(\bullet)$, minimum $(\perp)$ and maximum $(T)$ Total Suspended Solids concentrations (mg. $\left.\mathrm{L}^{-1}\right)$ in Canha, Pariquera-Açu and Jacupiranguinha Rivers, besides the number of samples $(\mathrm{N})$ for each case.
TSI results (Figure 9) showed, as expected, the increase of trophic state according to the level of anthropogenic impacts to which each river is submitted. In mean terms, Canha River presented a mesotrophic condition $(52<\mathrm{TSI}<59)$, exception to the river spring, where an oligotrophic state was verified. Pariquera-Açu presented a higher degree of TSI variation, reflecting oligotrophy (Rural area), mesotrophy (Spring), eutrophy (Urban area, Mouth) and even hyper-eutrophy (WTP effluent). Finally, TSI calculus for Jacupiranguinha River suggested that this river is severely affected by eutrophication. Some sampling stations presented TSI > 67 (Rural area, Industrial effluent and Mouth), what characterized a hyper-eutrophic condition.

\section{Discussion}

Nutrients' concentration is deeply linked to aquatic systems productivity and, therefore, with the eutrophication process. Eutrophication may naturally occur due to the aging of the environment or be related with artificial processes, normally inducted by anthropogenic impacts. The artificial eutrophication is associated with the input of organic pollution, which has in turn an effect on the water quality.

According to Moccellin et al. (2009), Jacupiranguinha River is influenced by both surface runoff from croplands and point sources of pollution (industrial and domestic effluents). Phosphorus from agricultural runoff gets into watercourses

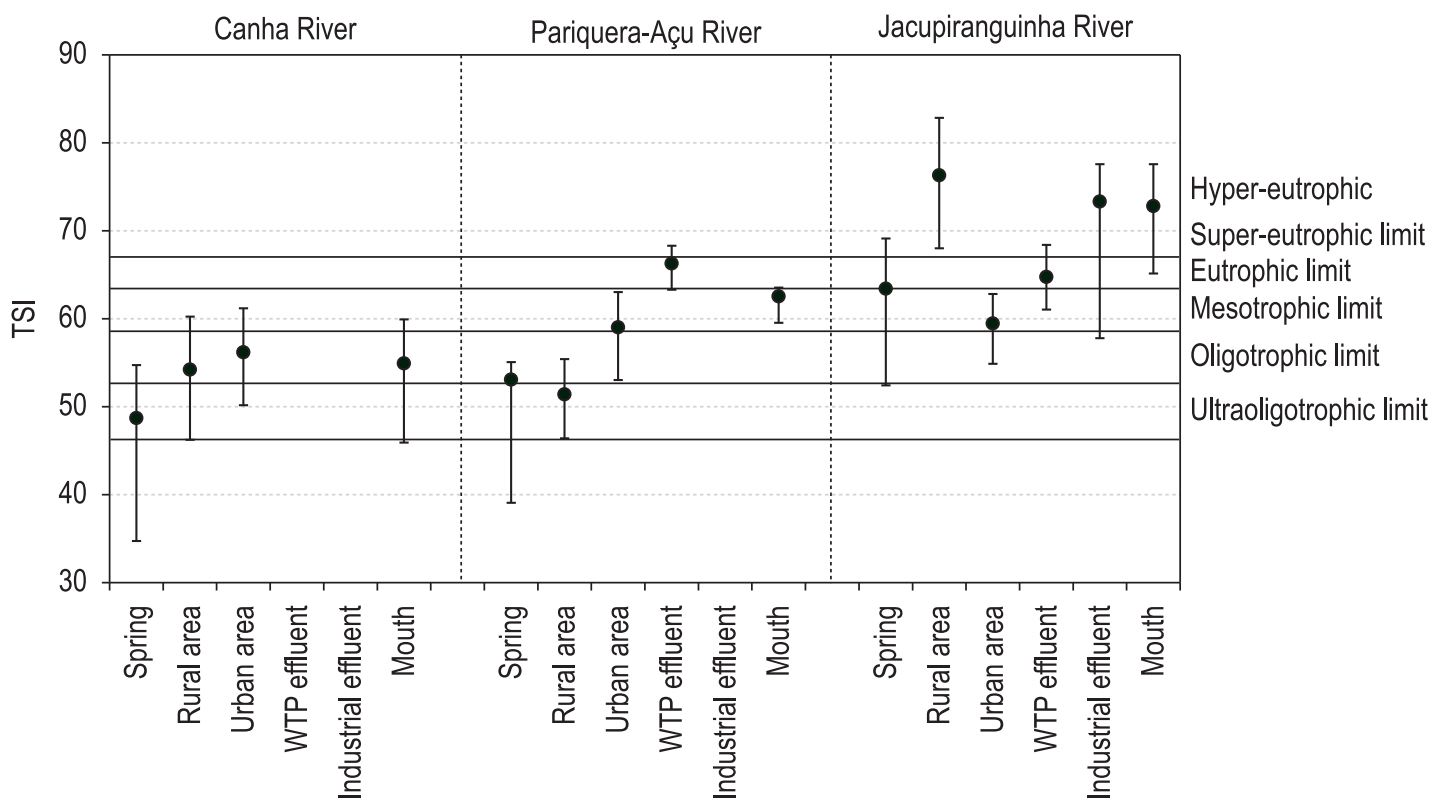

Figure 9. Mean $(\bullet)$, minimum $(\perp)$ and maximum $(\mathrm{T})$ TSI (Trophic State Index) in Canha, Pariquera-Açu and Jacupiranguinha Rivers. 
and is adsorbed in the sediment until particular conditions (e.g. dissolved oxygen depletion in the water) are reached to turn phosphorus bioavailable for assimilation by aquatic biota (Xavier, 2005). This author also commented that significant load of phosphorus to rivers and streams may be reduced with appropriate watershed management. However, the most prejudicial effect to Jacupiranguinha River is the huge increment on TP concentrations after the industrial (fertilizer manufacturing) effluent (maximum of about $124 \mathrm{mg} . \mathrm{L}^{-1}$, almost 1,250 times above the limit established by the Brazilian Council for the Environment, CONAMA, 2005).

Pariquera-Açu River presented intermediate TP concentrations, mainly influenced by the WTP effluent and by the lentic behavior verified in the river mouth. Pariquera-Açu River flows into Ribeira do Iguape River, a larger aquatic system that makes Pariquera-Açu River water velocity much lower in this sampling station. This situation probably boosted the following processes: i) aquatic macrophytes dissemination; ii) biomass decomposition; iii) phosphorus release from the sediment due to anoxic conditions on the interface water-sediment (Calijuri et al., 2008). Finally, Canha River was the aquatic system less impacted by TP, showing better water quality and lower trophic state in comparison to the others.

Groppo et al. (2008) mentioned that great part of medium Brazilian watersheds, mainly in São Paulo State, are impacted either by industrial effluents or by sewage. The authors also reported that the Piracicaba watershed (São Paulo State) presented severe water quality depreciation in the last years due to population growth. In this paper, the researchers found that the most affected water variables were Dissolved Oxygen, Biochemical Oxygen Demand, TN and TP. Phosphorus concentrations exceeded, in mean terms, $86 \%$ of the limit imposed by the Brazilian legislation.

Correspondingly, for Canha, Pariquera-Açu and Jacupiranguinha Rivers, TN concentrations in the water were influenced by agricultural activities. In this regard, Elmi et al. (2004) reported that nitrogen is an important pollutant of surface water and that agricultural runoff is able to carry this specie to the watercourses that drain rural areas. The authors also commented that nitrogen may favor artificial eutrophication, besides of fish mortality (Jarvie et al., 2008) studied two river basins in UK and demonstrated the importance of diffuse sources from agriculture to nutrients loads in the rivers, in special nitrogen species like total dissolved nitrogen and nitrate. In general, croplands, mainly those located in areas where there are not conservation practices, are the most prominent source of diffuse pollution to aquatic ecosystems (Xavier, 2005).

Mean TN concentrations were relatively high in the stations submitted to the rural areas influence: $2.0 \mathrm{mg} . \mathrm{L}^{-1}$ (Canha River), $1.5 \mathrm{mg} . \mathrm{L}^{-1}$ (PariqueraAçu River) and $2.6 \mathrm{mg} . \mathrm{L}^{-1}$ (Jacupiranguinha River). However, the highest TN concentrations in Pariquera-Açu and Jacupiranguinha Rivers were found in the stations influenced by the WTP (stabilization pond) effluent. These ponds are usually not able to remove nutrients, since these facilities uncommonly present design configurations for this purpose (Xian-Hua and Xia-Sheng, 1994; Lai and Lam, 1997).

Canha River presented the lowest Chl-a concentrations, probably as a result of both the riparian vegetation effect of shadowing and the lowest TP concentrations. Pariquera-Açu in turn presented a pattern of increasing Chl-a concentrations from the spring to its mouth, with notable peaks on the station that corresponded to the WTP effluent (maximum of $12.8 \mu \mathrm{g} . \mathrm{L}^{-1}$ ). This may be associated with the input of nutrients derived from this effluent, as verified by different researchers for other rivers (e.g. Owens and Walling, 2002; Neal et al., 2005), and also with allochthonous Chl- $a$ contribution from the stabilization pond. In general, stabilization ponds are a recurrent alternative for domestic wastewater treatment in Ribeira do Iguape Basin cities (Miwa et al., 2007). They usually present, as already discussed, poor efficiency on phosphorus and nitrogen removal and shelter high level of biomass growth, what justifies the allochthonous Chl-a contribution mentioned above. Although in São Paulo State most of the households are connected to conventional sewage system, only $20 \%$ of it is treated. In addition, the watercourses are commonly the final disposal of wastewater (Groppo et al., 2008).

Jacupiranguinha River presented high Chl-a concentrations from its spring, which is characterized by the lack of vegetation coverage. In general terms, Chl- $a$ concentrations were low in Canha River, intermediate in Pariquera-Açu River and high in Jacupiranguinha River, following therefore the level of anthropogenic impacts in each river. This is probably associated with the absence of forest cover and with the presence of widespread anthropogenic impacts (e.g. point and diffuse pollution sources) in the latter river, whose influence area showed the higher degree of human interference (Figure 4). 
The smaller the presence of riparian vegetation is, the higher algae content is (Roy et al., 2005). Halász et al. (2007) found higher concentrations of chlorophyll-a (average of $104.4 \mu \mathrm{g} . \mathrm{L}^{-1}$ ) in aquatic systems located in a Hungarian urban (and strongly modified) catchment area in comparison to a rural one. To summarize, urbanization is a process directly linked with the eutrophication of rivers and streams that drain urban regions. The growth of cities, illegal sewage connections and effluents from WTPs increase the load of pollutants to aquatic systems (Tucci et al., 2000; Taylor et al., 2004; Beyene et al., 2009).

TSS concentrations were also adequately related with land use schemes. The higher concentrations and also the bigger variation for this variable were observed in Jacupiranguinha River and the opposite for Canha River. Bilotta and Brazier (2008) presented a research about the influence of solids on water quality and aquatic biota, emphasizing that although they might have a damage effect, the solids occur under natural conditions on water bodies. The researchers cited that solids concentrations may be increased through anthropogenic influence, leading to physical changes (reduced light penetration, temperature changes and aggradation), chemicals ones (release of compounds such as heavy metals, pesticides and nutrients, besides DO depletion) and also biological ones (biota death as a result of physical and chemical modifications mentioned above).

According to results obtained for the three studied rivers, Jacupiranguinha River showed the highest mean TSS concentrations (up to $\left.100.1 \mathrm{mg} \cdot \mathrm{L}^{-1}\right)$. According to Bilotta and Brazier (2008), this concentration may reduce the algae primary production, decrease species diversity of benthic macroinvertebrates and increase the mortality of certain fish species. Low concentration found in Canha and Pariquera Açu Rivers may affect the aquatic biota as well, however at moderated levels.

High solids concentrations in the mouth of Canha River may be related with the contribution of solids from upstream as well as the land use that favors the input of allochthonous material. The urbanization process also helps the entrance of this material, since soils in this condition (unprotected and impermeable) work as particle carriers, especially in rainy seasons. In the case of these urban areas, it is also important to point that air pollution may increase the solids concentration in rainfall periods. Moccellin et al. (2009) commented that high concentrations of solids in Jacupiranguinha River were coupled with the leaching of the watershed, characterized by the lack of riparian forest.

TSI was recognized as an adequate tool for assessing the enrichment degree of the studied aquatic systems. The results suggested, as expected, that the rivers presented different levels of trophic state, from mesotrophic (Canha River) and meso-eutrophic (Pariquera-Açu River) to super-hyper-eutrophic (Jacupiranguinha River). For Canha River, the higher TSI was found in the urban area, what is linked with non-point pollution sources. On the other hand, it is interesting to observe that the higher TSI on Pariquera-Açu was found in the station influenced by the WTP effluent, which is a point source. For Jacupiranguinha River, it is important to stress a comment about this index. Although TP concentrations were extremely high in the station submitted to the industrial effluent, TSI was higher in the station that corresponded to the rural area. This is probably linked with the fact that the huge TP concentrations on the station downstream of the factory were no more consistently related or adhered with Chl- $a$, since tremendously high nutrients concentrations are able to inhibit biomass growth (Calijuri et al., 2008). Also in this case, the high TSS concentrations could have caused a limiting influence on phytoplanktonic community growth. Therefore, although TP concentrations were lower in the station downstream the rural area, Chl-a concentrations were higher than they were on the sampling site located downstream the factory, so the final result of TSI were higher in that case.

\section{Conclusions and Recommendations}

The assessment of land use influence on eutrophication-related water variables in three Brazilian rivers located in the same watershed but subjected to different levels of anthropogenic interference supported the following conclusions and recommendations:

- Canha, Pariquera-Açu and Jacupiranguinha Rivers, despite of their location in the same watershed, presented some significant differences in terms of environmental integrity, showing a gradient from low to high anthropogenic impacts, what was evident from data presented on land use patterns. Results showed that the trophic state of the rivers was directly linked with: i) sub-basin land use characteristics (presence of point sources of pollution, like industrial and WTP effluents, presence of agricultural, urban or forest 
coverage); ii) specific characteristics of each river channel and the contiguous influence area (absence of riparian forest, shadowing or direct exposure to sunlight, flow regime lentic or lotic behavior);

- TP, TN, Chl-a and TSS were recognized as sensitive variables when it comes to the assessment of the influence of soil use on water variables. This reflects the importance of employing these variables for monitoring purposes;

- In developing countries like Brazil, the imperative is to mitigate the impacts from point sources of pollution and, after that, start thinking about diffuse ones. Especially in the case of Jacupiranguinha River, that is a reliable example of great part of Brazilian urban rivers, the relative importance of point sources appeared to be much bigger than the influence of diffuse ones was. So, the most urgent action for improving this river health is to control the fertilizer's factory to discharge its toxic effluent into the river without previous treatment;

- Another suggestion is to enhance the technology to treat domestic wastewater of the cities, either by improving the conditions of the stabilization ponds or by adding some other structures to promote the improvement of the effluents in qualitative terms, therefore reducing the load of pollutants discharged into Pariquera-Açu and Jacupiranguinha Rivers; and

- It is expected that the set of information presented by this research may contribute to stimulate the local government and other public authorities to start projects to recover the water quality of Jacupiranguinha (as priority), Pariquera-Açu and Canha Rivers. Since all these rivers are used for water supply, investing in their environmental revitalization means enhancing in public health conditions, besides the ecological gaining.

\section{Acknowledgements}

The authors wish to express their sincere thanks to FAPESP (Fundação de Amparo à Pesquisa do Estado de São Paulo) for the financial support (Process 02/13449-1) to MC Calijuri and scholarship (Process 06/53550-4) to DGF Cunha. Also, to CNPq (Conselho Nacional de Desenvolvimento Científico e Tecnológico) for the scholarship to F Bottino.

\section{References}

American Public Health Association - APHA, 1999. Standard methods for the examination of water and wastewater. $20 \mathrm{ed}$. Washington.

ARIMORO, FO., 2009. Impact of rubber effluent discharges on the water quality and macroinvertebrate community assemblages in a forest stream in the Niger Delta. Chemosphere, vol. 77, no. 3, p.440-449

BASNYAT, P., TEETER, LD., LOCKABY, BG. and FLYNN, KM., 2000. The use of remote sensing and GIS in the watershed level analyses of nonpoint source pollution problems. Forest Ecology and Management, vol. 128, no. 1-2, p. 65-73.

BEYENE, A., LEGESSE, W., TRIEST, L. and KLOOS, H., 2009. Urban impact on ecological integrity of nearby rivers in developing countries: the Borkena River in highland Ethiopia. Environmental Monitoring and Assessment, vol. 153, no. 1-4, p. 461-476.

BILOTTA, GS. and BRAZIER, RE., 2008. Understanding the influence of suspended solids on water quality and aquatic biota. Water Research, vol. 42, no. 12, p. 2849-2861.

BOTTINO, F. and MENDIONDO, EM., 2009. Estudo experimental e matemático da qualidade de água visando à ecohidrologia fluvial: estudo de caso do rio Canha. In CALIJURI, MC., MIWA, ACP. and FALCO, PB. (Orgs.). Subsídios para a sustentabilidade dos recursos hídricos: um estudo de caso em sub-bacias do Baixo Ribeira de Iguape, São Paulo, Brasil. São Carlos: USP. p. 123-138.

BUCK, O., NIYOGI, DK. and TOWNSEND, CR., 2004. Scale-dependence of land use effects on water quality of streams in agricultural catchments. Environmental Pollution, vol. 130, no. 2, p. 287-299.

CALIJURI, MC., ALVES, MAS. and SANTOS, ACA., 2006. Cianobactérias e cianotoxinas em água continentais. São Carlos: Rima. 109 p.

CALIJURI, MC., CUNHA, DGF., QUEIROZ, LA., MOCCELLIN, J. and MIWA, ACP., 2008. Nutrients and chlorophyll- $a$ concentrations in tropical rivers of Ribeira do Iguape Basin, SP, Brazil. Acta Limnologica Brasilensia, vol. 20, no. 2, p. 131-138.

Companhia de Tecnologia de Saneamento Ambiental CETESB, 2005. Relatório de água interiores no Estado de São Paulo. São Paulo. Available from: www.cetesb. sp.gov.br. Access: 07/19/2009.

Centro Tecnológico da Fundaçâo Paulista de Tecnologia e Educaçáo - CETEC, 2005. Relatório de situação dos recursos hidricos da UGRHI 11. São Paulo: Comitê da Bacia Hidrográfica do Ribeira de Iguape e Litoral Sul. Available from: www.sigrh.sp.gov.br. Access in: 06/08/2009.

Conselho Nacional do Meio Ambiente - CONAMA, 2005. Resolução CONAMA 357, de 17 de Março de 2005. Dispóe sobre a classificação dos corpos de água e diretrizes ambientais para o seu enquadramento, bem como estabelece as condiçóes e padróes de lançamento 
de efluentes, e dá outras providências. Brasília. Available from: www.mma.gov.br/port/conama/res/ res05/res35705.pdf. Access in: 10/07/2009.

CUNHA, DGF., FALCO, PB. and CALIJURI, MC., 2008. Densidade fitoplanctônica e estado trófico dos rios Canha e Pariquera-Açu, bacia hidrográfica do rio Ribeira de Iguape, SP, Brasil. Revista Ambiente e Água, vol. 3, no. 2, p. 90-105.

DODDS, WK., 2006. Eutrophication and trophic state in rivers and streams. Limnology and Oceanography, vol. 51, no. 1, p. 671-680.

DODDS, WK., JONES, JR. and WELCH, EB., 1998. Suggested classification of stream trophic state: distributions of temperate stream types by chlorophyll, total nitrogen and phosphorus. Water Research, vol. 32, no. 5, p. 1455-1462.

DODDS, WK., SMITH, VH. and LOHMAN, K., 2002. Nitrogen and phosphorus relationships to benthic algal biomass in temperate streams. Canadian Journal of Fisheries and Aquatic Sciences, vol. 59, no. 5, p. 865-874.

ELMI, AA., MADRAMOOTOO, C., MOHAMUD, E. and HAMEL, C., 2004. Water and fertilizer nitrogen management to minimize nitrate pollution from cropped soil in a southwestern Quebec, Canada. Water, Air and Soil Pollution, vol. 151, no. 1-4, p. 117-134.

Fundação Sistema Estadual de Análise de Dados SEADE, 2000. População e Estatísticas Vitais. São Paulo. Available from: www.seade.gov.br. Access in: 04/03/09.

Fundação Sistema Estadual de Análise de Dados SEADE, 2003. População e Estatísticas Vitais. São Paulo. Available from: www.seade.gov.br. Access in: 04/03/09.

Fundação Sistema Estadual de Análise de Dados SEADE, 2006. População e Estatísticas Vitais. São Paulo. Available from: www.seade.gov.br. Access in: 04/03/09.

GARNIER, J., NÉMERY, J., BILLEN, G. and THÉRY, S., 2005. Nutrient dynamics and control of eutrophication in the Marne River system: modelling the role of exchangeable phosphorus. Journal of Hydrology, vol. 304, no. 1-4, p. 397-412.

GROPPO, JD., MORAES, JM., BEDUSCHI, CE., GENOVEZ, AM. and MARTINELLI, LA, 2008. Trend analysis of water quality in some river with different degrees of development within the Sao Paulo State, Brazil. River Research and Applications, vol. 24, no. 8, p. 1056-1067.

HALÁSZ, G., SZLEPÁK, E., SZILÁGYI, E., ZAGYVA, A. and FEKETE, I., 2007. Application of EU Water Framework Directive for monitoring of small water catchment areas in Hungary, II. Preliminary study for establishment of surveillance monitoring system for moderately loaded (rural) and heavily loaded (urban) catchment areas. Microchemical Journal, vol. 85 , no. 1 , p. $72-79$.
Instituto Brasileiro de Geografia Estatística - IBGE, 2003. Base Cartográfica: Vale do Ribeira (SP). Brasil. Available from: www.ibge.gov.br. Access in: 11/11/2006.

JARVIE, HP., WITHERS, PJA., HODGKINSON, R., BATES, A., NEAL, M., WICKHAM, HD., HARMAN, AS. and ARMSTRONG, L., 2008. Influence of rural land use on streamwater nutrients and their ecological significance. Journal of Hydrology, vol. 350, no. 3-4, p. 166-186.

KHAN, FA. and ANSARI, AA., 2005. Eutrophication: an ecological vision. The Botanical Review, vol. 71, no. 4, p. 449-482.

KIM, G., YUR, J. and KIM, J., 2007, Diffuse pollution loading from urban stormwater runoff in Daejeon city, Korea. Journal of Environmental Management, vol. 85, no. 1, p. 9-16.

LAI, PCC. and LAM, PKS., 1997. Major pathways for nitrogen removal in waste water stabilization ponds. Water, Air, and Soil Pollution, vol. 94, no. 1-2, p. 125-136.

LAMPARELLI, MC., 2004. Graus de trofia em corpos d'água do Estado de São Paulo: avaliação dos métodos de monitoramento. São Paulo: Universidade de São Paulo. 235 p. [Tese de Doutorado]

LOURES, SSP., 2008. Ambientes, uso e ocupação do solo e zoneamento estratégico para as sub-bacias dos rios Jacupiranga e Pariquera-Açu, Vale do Ribeira, SP. Viçosa: Universidade Federal de Viçosa. 180 p. [Tese de Doutorado]

LOURES, SSP., CALIJURI, ML., SCHAEFER, CEGR. and SANTIAGO, AF., 2009. Abordagem geoambiental para planejamento em regióes tropicais. Estudo de caso: Vale do Ribeira de Iguape, SP. In CALIJURI, MC., MIWA, ACP. and FALCO, PB. (Orgs.). Subsidios para a sustentabilidade dos recursos hídricos: um estudo de caso em sub-bacias do Baixo Ribeira de Iguape, São Paulo, Brasil. São Carlos: USP. p. 33-52.

LUGÃO, WG., CALIJURI, ML. and LOURES, SSP., 2009. Caracterização da bacia hidrográfica do rio Jacupiranguinha. In CALIJURI, MC., MIWA, ACP. and FALCO, PB. (Orgs.). Subsidios para a sustentabilidade dos recursos hidricos: um estudo de caso em sub-bacias do Baixo Ribeira de Iguape, São Paulo, Brasil. São Carlos: USP. p. 17-32.

MARQUES, JC., NIELSEN, SN., PARDAL, MA. and JORGENSEN, S., 2003. Impact of eutrophication and river management within a framework of ecosystem theories. Ecological Modelling, vol. 166, no. 1-2, p. 147-168.

MIWA, ACP., FREIRE, RHF. an d CALIJURI, MC., 2007. Dinâmica de nitrogênio em um sistema de lagoas de estabilização na região do Vale do Ribeira (São Paulo, Brasil). Engenharia Sanitária e Ambiental, vol. 12, no. 2, p. 169-180.

MOCCELLIN, J., CUNHA, CAG., FERRAZ, IC. and CALIJURI, MC., 2009. Comparação entre 
as características físicas e químicas da água dos rios Jacupiranga, Jacupiranguinha, Pariquera-Açu e Canha, Vale do Ribeira de Iguape, SP. In CALIJURI, MC., MIWA, ACP. and FALCO, PB. (Orgs.). Subsidios para a sustentabilidade dos recursos hidricos: um estudo de caso em sub-bacias do Baixo Ribeira de Iguape, São Paulo, Brasil. São Carlos: USP, 2009. p. 87-108.

MORGAN, AM., ROYER, TV., DAVID, MB. and GENTRY, LE., 2006. Relationships among Nutrients, Chlorophyll- $a$, and Dissolved Oxygen in Agricultural Streams in Illinois. Journal of Environmental Quality, vol. 35, no. 4, p. 1110-1117.

NAVAL, LP. and SANTOS, LMP., 2000. Avaliação de um sistema de lagoas de estabilização para tratamento de águas residuárias domésticas na Região Norte. In Anais do 27 Congresso Interamericano de Engenharia Sanitária e Ambiental. Porto Alegre: ABES. 7 p.

NEAL, C., JARVIE, HP., NEAL, M., LOVE, AJ., HILL, L. and WICKHAM, H., 2005. Water quality of treated sewage effluent in a rural area of the upper Thames Basin, Southern England, and the impacts of such effluents on riverine phosphorus concentrations. Journal of Hydrology, vol. 304, no. 1-4, p. 103-117.

NEDEAU, EJ., MERRITT, RW. and KAUFMAN, MG., 2003. The effect of an industrial effluent on an urban stream benthic community: water quality vs. habitat quality. Environmental Pollution, vol. 123, no. 1 , p. 1-13.

Netherlands Norm - NEN. NEN 6520. Netherlands, 1981.

NYAMANGARA, J., BANGIRA, C., TARUVINGA, T., MASONA, C., NYEMBA, A. and NDLOVU, D., 2008. Effects of sewage and industrial effluent on the concentration of $\mathrm{Zn}, \mathrm{Cu}, \mathrm{Pb}$ and $\mathrm{Cd}$ in water and sediments along Waterfalls stream and lower Mukuvisi River in Harare, Zimbabwe. Physics and Chemistry of the Earth, vol. 33, no. 8-13, p. 708-813.

NUSH, EA., 1980. Comparison of different methods for chlorophyll and pheopigment determination. Archiv für Hydrobiologie, vol. 14, p. 14-36.

ODUM, E., 1971. Fundamental of ecology. 3 ed. Philadelphia: Sanders Company. 574 p.

OLIVEIRA, R., SILVA FILHO, TAT., MOREIRA, JFV. and SILVA, AS., 2001. Análise fatorial de uma série de lagoas de estabilizaçáo rasas tratando esgoto doméstico no Nordeste do Brasil. In Anais do 21 Congresso Brasileiro de Engenharia Sanitária e Ambiental. João Pessoa: ABES. 8 p.

PISCART, C., GENOEL, R., DOLEDEC, S., CHAUVET, E. and MARMONIER, P., 2009. Effects of intense agricultural practices on heterotrophic processes in streams. Environmental Polluttion, vol. 157, no. 3, p. 1011-1018.

RIBEIRO, LHL., BRANDIMARTE, AL. and KISHI, RT., 2005. Formation of the Salto Caxias Reservoir
(PR): an approach on the eutrophication process. Acta Limnologica Brasiliensia, vol. 17, no. 2, p. 155-165.

ROY, AH., FAUST, CL., FREEMAN, MC. and MEYER, JL., 2005. Reach-scale effects of riparian forest cover on urban stream ecosystems. Canadian Journal of Fisheries and Aquatic Sciences, vol. 62, no. 10, p. 2312-2329.

SALVIA-CASTELLVÍ, M., IFFLY, JF., BORGHT, PV. and HOFFMANN, L., 2005. Dissolved and particulate nutrient export from rural catchments: a case study from Luxembourg. Science of the Total Environment, vol. 344, no. 1-3, p. 51-65.

SMITH, VH., 2003. Eutrophication of Freshwater and Coastal Marine Ecosystems: a global problem. Environmental Science \& Pollution Research, vol. 10, no. 2, p. 126-139.

SMITH, VH., TILMAN, GD. and NEKOLA, JC., 1999. Eutrophication: impacts of excess nutrients inputs on freshwater, marine, and terrestrial ecosystems. Environmental Pollution, vol. 100, no. $1-3$, p. $179-196$.

TAYLOR, GD., FLETCHER, TD., WONG, THF., BREEN, PF. and DUNCAN, HP., 2005. Nitrogen composition in urban runoff: implications for stormwater management. Water Research, vol. 39, no. 10, p. 1982-1989.

TAYLOR, SL., ROBERTS, SC., WALSH, CJ. and HATT, BE., 2004. Catchment urbanisation and increased benthic algal biomass in streams: linking mechanisms to management. Freshwater Biology, vol. 49 , no. 6 , p. $835-851$.

TUCCI, CEM., HESPANHOL, I. and CORDEIRO NETO, OM., 2000. Cenários da gestão da Água no Brasil: uma contribuição para a "visão mundial da água”. Revista Brasileira de Recursos Hidricos, vol. 5, p. 31-43.

XAVIER, CF., 2005. Avaliação da influência do uso e ocupação do solo e de características geomorfológicas sobre a qualidade das águas de dois reservatórios da região metropolitana de Curitiba, Paraná. Paraná: Universidade Federal do Paraná. 167 p. [Dissertação de Mestrado]

XIAN-HUA, W., YI, Q. and XIA-SHENG, G., 1994. Graphical presentation of the transformation of some nutrients in a wastewater stabilization pond system. Water Research, vol. 28, no. 7, p. 1659-1665.

WOOD, FL., HEATHWAITE, AL. and HAYGARTH, PM., 2005. Evaluating diffuse and point phosphorus contributions to river transfers at different scales in the Taw catchment, Devon, UK. Journal of Hydrology, vol. 304, no. $1-4$, p. 118-138.

Received: 16 October 2009 Accepted: 17 March 2010 